\title{
From Confidence to Confusion: Structure and Meaning in Psalm 27
}

\author{
Benjamin D. Sommer
}

At once a song of faith and a song of doubt, Psalm 27 can be seen as a distillation of the Book of Psalms as a whole. ${ }^{1}$ Its stanzas move from a complete but perhaps haughty faith in God to a more modest religious sentiment: hope, a less-than-full trust which aspires to confidence but admits to some uncertainty. Psalm 27 divides itself into three stanzas, and the relationship among them provides a key to the meaning of this poem. Each section has its own mood: in the first section (verses 1-6) the worshiper is confident; in the second (7-12), the worshiper is distressed; in the third (13-14), we find expressions of hope along with an implicit acknowledgement that certainty of salvation is not possible. The sections are stylistically distinct as well: in the first section, the worshiper speaks of God in the third person; in the second, the worshiper addresses God in the second person; in the third, God is again described in the third person. The shift in both mood and grammatical person at verse 7 is extremely abrupt, and this has led some scholars to argue that our chapter contains two unrelated psalms, a song of confidence in verses 16 and a complaint/plea psalm in verses $7-14$. But such a view oversimplifies our poem. It fails to note the ways each section contains elements that foreshadow or echo the others. ${ }^{2}$ Intimations of distress can be found in the first stanza, while elements of confidence underlie the worshiper's plea for help in the second. The psalm's movement back and forth between confidence and need, between believing in God's reliability and worrying about God's absence,

1 Abbreviations in the notes follow the stylesheet of the Society for Biblical Literature. All translations are my own, unless otherwise noted. It is an honor to dedicate this essay to Professor Joel Roth as a small token of thanks for all he has taught and for the many שאלות he has answered for me and my family over the years. My thanks to Rabbi Joyce Newmark for her careful reading of the galleys.

2 The same situation is found in Psalm 19: each of the two stanzas that many scholars regard as distinct and unrelated psalms is in fact full of verbal and thematic references to the other, and it is the dialogue between the two stanzas that is the key to understanding that highly integrated, unified poem. See Benjamin D. Sommer, "Nature, Revelation, and Grace in Psalm 19: Towards a Theological Reading of Scripture," HTR 108 (2015): esp. 379-381, 388-39o. 
reveals the essence of this psalm. The psalm as a whole defines a mature faith in God as encompassing doubt. This psalm further emphasizes not only intellectual knowledge of God as a savior but the experience of God's presence, which comes not only from contemplation but from ritual or ethical action.

\section{Text and Translation}

In analyzing this text, I would like to model a method of reading in which we'll first attend to local poetic structures; building on these local structures, we'll move to broader structural elements; finally, building on the broader structures, we'll turn to theological interpretation. So I think it would be worthwhile to take a look at the text as a whole and to attend to its lineation, because the first thing we need to do when we are interpreting any biblical poem is to break it into lines. In most poetic traditions, that work is done for us. When one picks up The Oxford Book of English Verse or The Penguin Anthology of Twentieth-Century American Poetry or this week's copy of The New Yorker, the conventions of printing tell us how the poet wants the poem to be divided. Further, in traditions in which poetry scans (that is, in poems that have meter), we usually know quite precisely where lines begin and end based on the number of syllables they contain and on their patterns of stress (in most English poetry prior to the twentieth century, for example) or vowel length (in Greek, Arabic, and medieval Hebrew poetry). But in biblical poetry we have no authoritative editions going back to the time of the poems' composition or evolution. Because biblical poetry is essentially a form of free verse, ${ }^{3}$ there is no

3 See F.W. Dobbs-Allsopp, On Biblical Poetry (New York: Oxford University Press, 2015), 9-10, 95177, esp. 98-99. Similarly, Benjamin Hrushovski, "Prosody, Hebrew," in Encyclopaedia Judaica (Jerusalem: Keter, 1971), 13:1201, refers to the "free rhythm ... based on a cluster of changing principles" of biblical poetry, which he clearly sees as a type of free verse. On earlier literary critics (esp. Gay Wilson Allen) who rightly recognize biblical poetry as a very early form of free verse, see Dobbs-Allsopp, On Biblical Poetry, 95, 393 n. 3, and 396 n. 32. Dobbs-Allsopp points out (177 and 395 n. 13) that Walt Whitman himself already implied a connection between what we now call free verse and biblical poetry in his 1888 essay, "The Bible as Poetry." Whitman cites the claim of Frederick De Sola Mendes (in Mendes' lecture "Hebrew Poets") that "that rhyming was not a characteristic of Hebrew poetry at all. Metre was not a necessary mark of poetry. Great poets discarded it; the early Jewish poets knew it not." Mendes, incidentally, was one of the founders of the Jewish Theological Seminary of America and a graduate of the older JTs in Breslau, Germany. (He is not to be confused with his brother, Henry Pereira Mendes, the American JTs's president from 1897 to 1902.) Whitman's essay is available in Walt Whitman, "The Bible as Poetry," in Complete Prose Works (Philadelphia: David McKay, 1892), 379-382. I have not been able to locate Mendes' lecture, which (Dobbs-Allsopp suggests to me) may not exist in print; Whitman may have attended the lecture in Manhattan where he 
scansion to determine where lines begin and end. So the readers have to figure this out themselves, and it will be helpful for readers of this commentary to know how I divide the poem into lines and versets. (I will follow Benjamin Harshav (Hrushovski) in labeling the two or three sub-units of a biblical poetic line as versets. $\left.{ }^{4}\right)$

\begin{tabular}{|c|c|c|c|c|}
\hline & & & לדוד & 1 \\
\hline & ממי אירא & & ה' אורי וישעי & \\
\hline & ממי אפחד: & & ה' מעוז־חיי & \\
\hline & לאכל את־בשרי & & בקרב עלי מרעים & 2 \\
\hline & המה כשלו ונפלו: & & צרי ואיבי לי & \\
\hline & לא־יירא לבי & & אם־תחנה עלי מחנה & 3 \\
\hline & בזאת אני בוטח: & & אם־תקום עלי מלחמה & \\
\hline & אותה אבקש & & אחת שאלתי מאת־ה' & 4 \\
\hline & כל־ימי חיי & & שבתי בבית־ה' & \\
\hline & ולבקר בהיכלו: & & לחזות בנעם־ה' & \\
\hline & ביום רעה & & כי יצפנני בסכה & 5 \\
\hline & בצור ירוממני: & & יסתרני בסתר אהלו & \\
\hline & על איבי סביבותי & & ועתה ירום ראשי & 6 \\
\hline אשירה ואזמרה לה': & זבחי תרועה & & ואזבחה באהלו & \\
\hline \multirow[t]{6}{*}{ וחנני וענני: } & קולי אקרא & & שמע־ה' & 7 \\
\hline & בקשו פני & & לך אמר לבי & 8 \\
\hline & אל־תסתר פניך ממני & 9 & את־פניך ה' אבקש: & \\
\hline & עזרתי היית & & אל־תט־באף עבדך & \\
\hline & א־להי ישעי: & & אל־תטשני ואל־תעזבני & \\
\hline & וה' יאספני: & & כי־אבי ואמי עזבוני & 10 \\
\hline למען שוררי: & ונחני בארח מישור & & הורני ה' דרכך & 11 \\
\hline ויפח חמס: & כי קמו־בי עדי־שקר & & אל־תתנני בנפש צרי & 12 \\
\hline בארץ חיים: & לראות בטוב־ה' & & לולא האמנתי & 13 \\
\hline וקוה אל־ה': & חזק ויאמץ לבך & & קוה אל־ה' & 14 \\
\hline
\end{tabular}

1 Of David.

Yhwh is my light and my salvation-

Whom should I fear?

Yhwh is the sure haven of my life-

Whom could I dread?

2 When evil-doers draw near

To slander me,

My enemies and foes-

They're the ones who stumbled and fell.

lived for some years and where Mendes served as rabbi of the synagogue now known as Temple Shaarey Tefilla.

4 Hrushovski, "Prosody, Hebrew," 13:1200-1203. 
3 Should an army encamp against me, Should war break out around me,

4 One thing I ask of Yhwh, To dwell in Yhwh's house To gaze upon the marvel that is Yhwh,

5 For He conceals me, inviolable, in His shelter, He hides me in His hidden tent,

6 So now, I hold my head high I should offer up in His tent
My mind will know no fear.

I will trust in this.

This do I request:

All the days of my life,

And to serve in His palace.

At times of danger;

High on a rock, He lifts me up.

Above my enemies all around.

A celebration-meal-

I should sing and play music to Yhwh!

7 Hear, O Yhwh,

My voice, my cry!

And show me grace and answer me!

8 On Your behalf my mind speaks:

"Seek Me out!"

It is You I seek, Yhwh-

9 Do not hide Yourself from me!

Don't thrust Your servant away in anger-

You were my help!

Don't leave me, don't abandon me

O God of my salvation!

10 Indeed, my father and mother abandoned me,

But it is Yhwh who takes me in.

11 Parent me, Yhwh, teaching me Your path,

And lead me on a level road

While my foes look on.

12 Don't feed me to my enemies!

Yes, lying witnesses rise against me,

With unfair, violent testimony.

13 Were it not for the fact that I believe

That I shall see Yhwh's goodness

While still alive ...

14 Hope that Yhwh will come!

Courage! Let your mind be strong!

And hope that Yhwh will come.

\section{Commentary}

\section{Verse 1.}

The opening verse consists of two lines that are lexically parallel to each other: each word in the first line of the verse corresponds precisely to a word in the next. Each line contains two versets in which the second spells out the result of the first: because God is my salvation and stronghold, there is no reason for me to fear.

M, Sure haven Literally, "mountain stronghold, place of refuge." The word can refer to a fortress or fortified city, but it is also often used as a metaphor for God, e.g., Psalm 31:5, 37:39, 52:9; Isaiah 25:4; Jeremiah 16:19; Nahum 1:7; 
and, most familiarly to many contemporary Jews, in the opening line of the medieval hymn, מעוז צור.

\section{Verse 2.}

קרב echoes the noun meaning "battle," lending it a secondary sense that hints at "setting out to war" (see ibn Ezra and Radaq to this verse).

, לאכל את בשרי To slander me Literally, "to eat my flesh." This phrase allows several plausible interpretations. It could be understood as a metaphor for the actions of the worshiper's enemies. The metaphor implicitly compares the enemies to wild animals. This understanding of the phrase works especially well if we are understanding the enemies to be an army attacking Judah (though this seems less likely for a psalm whose speaker is an individual, not the nation), or if they are individuals who violently attack the speaker. At the same time, however, similar phrases in Aramaic (קרציה אכל) and Akkadian (qarși akälu) are idioms meaning "slander someone" and (in Akkadian) "initiate legal proceedings against someone, accuse someone." Thus this speaker of the psalm could be referring to enemies who are unjustly accusing him of some misdeed, either as gossip or in a formal legal setting. This ambiguity need not be resolved by the modern interpreter; some worshipers reciting this psalm (whether in biblical times or later) might have justifiably intended these words as a metaphor for violence or warfare, while others intended it, with equal justification, as the idiom for slander or for unjust legal proceedings.

, צעי ואיבי לי first-person possessive particle לי לי after the first-person possessive suffixes of the nouns. Such doubling is a characteristic the elevated language employed in ancient Hebrew poetry. Cf., e.g., כרמי שלי in Song of Songs 8:12.

המה כשלו ינפלו They're the ones who stumbled and fell The Hebrew emphasizes "they" by adding the pronoun המה, since the plural form of the Hebrew verbs already indicates the subject. ${ }^{5}$

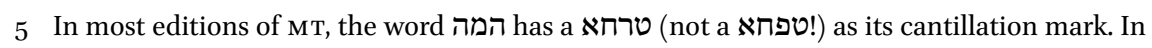
the cantillation of the טרחא the טפרי אמ"ת is a conjunctive cantillation mark, and conse-

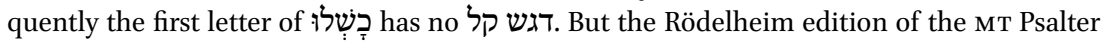
edited by Seeligman Isaac Baer, which many siddurim follow, has a המה on רביע מוגרש, which

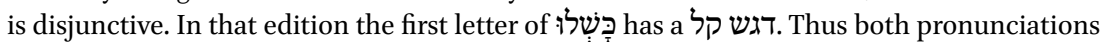


בשלז ונפלי Stumbled and fell Contrary to the NJPS translation ("stumble and fall"), the suffix verbs in the Hebrew text do not have the frequentative meaning implied by the English present tense.

The parallelism in the second line of this verse is unusual. Had the poet צרי כשלו / ואיבי לי נפלו employed a more typical pattern, the line would read ("My foes stumbled, / my adversaries fell"). But instead the line clusters nouns in its first verset and verbs in the second. This phrasing allows uncertainty to build up in the first verset, finally to be resolved in the second, whereas the more typical parallelism would have eliminated it immediately. ${ }^{6}$ The implications of this intimation of disquiet in the first stanza (which is largely confident in tone) will be discussed in "Interpretation," below.

\section{Verse 3.}

,אם־תחנה עלי מחנה...אם־תקים עלי מלחמה , Should an army encamp against me ... Should war break out around me These two lines pick up the hint of warfare in the previous verse's verb בקרב ("draw near", but from a root that also means battle), developing the martial metaphor explicitly.

בזע, In this This could also be rendered, "nevertheless, even so." But the ב־ בטח בטח when used with the verb confident, or "trust") regularly introduces the person or thing that the verb's subject trusts. In that case, we must ask what this refers to. It could refer back to the confidence the speaker expressed in the previous two verses ("Though beset by enemies, I remain confident, because God who is my light and salvation is more powerful than encroaching armies"); so Rashi, Radaq, Hakham. ${ }^{8}$ Or "this" might refer forward to the request made in the next verse to dwell permanently in the Temple ("Though beset by enemies, I will be safe as long as I remain at the Temple"); so ibn Ezra. On this final possibility, see the discussion of "Settings" in the section, "Interpretation," below.

may be regarded as correct, as are the various siddurim that adopt the one or the other. (The אדם evidence of Rödelheim editions is of particular import, as they were used already by גו עדן in is evidenced by God's characterization of Adam in Gen 3:9b 3 .)

6 See John Goldingay, Psalms 1-41, Baker Commentary on the Old Testament Wisdom and Psalms (Grand Rapids, MI: Baker Academic, 20o6), 391.

7 Arnold Ehrlich, Psalmen: Neu uebersetzt und erklaert (Berlin: M. Poppelauer, 1905), ad loc. Hence NJPS: "Still."

8 Amos Hakham, The Book of Psalms, 2 vols. [in Hebrew], Da'at Mikra (Jerusalem: Mosad Harav Kook, 1979), ad loc. 


\section{Verse 4 .}

שאלתי...אבקש Ask ... request The request here adds an element that will be developed more in the second stanza. But even with the request, the tone of this verse remains confident.

לחזית בנעם, To gaze upon the marvel Elsewhere in the ancient Near East, statues of worshipers were sometimes installed at temples. ${ }^{9}$ Such statues, which typically have unusually large eyes, evince the delight of the worshipers who bask in the presence of their deity. ${ }^{10}$ In the Babylonian temples, actual worshipers did not come close enough to the statues of the deities to literally have enjoyed gazing at them. ${ }^{11}$ The mere experience of seeing the temple building and spending time in it was enough to produce the joy. Similarly, the phrase in the psalm here does not mean literally seeing God's presence in the Holy of Holies, which was inaccessible to normal worshipers and even most priests. ${ }^{12}$ Rather, as Craigie and Tate note, the phrase is "not to be interpreted literally, but as implying the extraordinary experience of God's beauty and glory as symbolized in the temple, specifically in the Ark."13 In this verse, the worshiper expresses a yearning not merely to know something about God but to bask in the delightful warmth of God's presence in the building where, Israelites believed, God actually dwelt on earth. As Martin Cohen astutely notes in his commentary on this psalm, "The poet wants to cultivate the experiential, rather

9 See Shalom Holtz, "God as Refuge and Temple as Refuge in the Psalms," in The Temple of Jerusalem: From Moses to the Messiah: Studies in Honor of Professor Louis H. Feldman, ed. Steven Fine (Leiden: Brill, 2011), 26.

10 On this theme in Psalms and elsewhere in the Bible, see Othmar Keel, The Symbolism of the Biblical World: Ancient Near Eastern Iconography and the Book of Psalms, trans. Timothy J. Hallett (New York: Seabury Press, 1978), 314. For pictures of such statues which give a clear sense of this delight, see James B. Pritchard, ed., The Ancient Near East in Pictures Relating to the Old Testament, 2d ed. (Princeton: Princeton University Press, 1969), nos. 1824.

11 See Ivan Hrůša, Ancient Mesopotamian Religion: A Descriptive Introduction, trans. Michael Tait (Münster: Ugarit Verlag, 2015), 73; Michael B. Hundley, Gods in Dwellings: Temples and Divine Presence in the Ancient Near East (Atlanta: Society of Biblical Literature, 2013), 4875, esp. 68-69 and 75 .

12 Theoretically, that presence was in fact visible; but seeing it directly would cause death instantly (Exod 33:20), though exceptions did occur (e.g., Isa 6:1-2, in which the prophet is initially dismayed because he expects to die after seeing God's presence; Exod 24:17, in which the people at the bottom of Mt. Sinai see God's presence on top of the mountain, surrounded by a thick cloud but apparently still visible through the cloud due to its intense brightness).

13 Peter Craigie and Marvin Tate, Psalms 1-50, 2d. ed., wвC (N.p.: Thomas Nelson, 2004), 232. 
than merely intellectual, knowledge of God ... to know God through the senses rather than through the intellect."14 For another verse that stresses this experiential knowledge of God through the senses and not just the intellect, see Psalm 34:9.

לבקר, To serve Contrary to NJPS, ${ }^{15}$ which translates "to frequent," in ancient forms of Hebrew this verb does not mean to visit or to come regularly to a particular place; that meaning of the verb develops only in modern Hebrew. Rather, in biblical, Qumran, and rabbinic Hebrew, this verb has a range of meanings relating to "carrying out important tasks." It can mean "to examine, to check," especially to examine sacrificial offerings so as to ensure that they are ritually appropriate. It can also mean "to be in charge, to take care of." Thus in the Dead Sea Scrolls the מבקר is the official in charge of the community. ${ }^{16}$ In rabbinic Hebrew, the sense of "take care of" appears in reference to the sick, in the well-known phrase, ביקור חולים. In modern Jewish parlance, this phrase is used to refer to visiting the sick, an ethically commendable action that generally involves dropping by to cheer up a sick person. But in ancient times, when there were no hospitals and few physicians, ביקור חולים had a different meaning that fits the basic definition of the verb לבקר noted above: it denoted examining and taking of a sick person, attending to their needs in the ways that medical professionals (especially nurses) and hospital staff members do today. Neighbors and relatives who performed the act of ביקור חולים in antiquity were not just coming over to chat. They fed and bathed the patient, applied ointments and salves to their sores, or prepared medicinal herbs for them. In modern Hebrew, the meaning of this verb meaning extends much further, to include social visits, tourism, and vacations (one can מבקר Disney World, for example, without providing medicine for Mickey Mouse or drugs for Donald Duck). This broader sense of the verb developed out of the much more specific meaning of the phrase in older forms of Hebrew.

Thus the worshiper in our verse is not asking to be able to stop in at the temple on frequent occasions. The worshiper wants to some responsibility that will keep him there on a long-term basis. ${ }^{17}$ What emerges from this verb (viz., that

14 Martin Samuel Cohen, Our Haven and Our Strength: The Book of Psalms (New York: Aviv Press, 2004), 79.

15 Which follows Ehrlich, Psalmen, ad loc.

16 This meaning appears in particular in Serah Hayahad (the Community Rule) and in the Damascus Document.

17 Some scholars attempt to identify the job more specifically. Malul (in Sarna, 'Olam Hata- 
the speaker wants to remain at the temple permanently, not simply to visit it) matches what we see earlier in this verse: the speaker wants to dwell in Yhwh's house all the days of my life. What circumstances might have led the speaker of this psalm to want to remain at the temple will be discussed below in "Interpretation."

\section{Verse 5 .}

"יצפנים He conceals me, inviolable Throughout the verse, the prefix verbs are best understood as frequentative. The verb צפן refers to hiding something valuable. (The passive participle of this verb, צפוּן ["hidden thing"], is used in the Passover Haggadah as another name for the אפיקומן that is hidden after the seder meal.) The root of this verb also produces the noun wפוֹ, which means "north." That noun appears frequently in Ugaritic literature as the name of the mountain where the gods and goddesses live; in other words, it is the Ugaritic equivalent to Mount Olympus of the Greeks. ${ }^{18}$ This mythological sense of the word as connected with heavenly dwellers and with creation occasionally occurs in biblical texts (Isa 14:13; Ps 89:13; Job 26:7). Psalm 48:3 uses this noun as an appellation for Mount Zion; since צפון can mean the hilltop where a deity lives, and since Yhwh dwells in the Temple on Mount Zion, Psalm 48 can use the term in the course of arguing that Jerusalem, as the city where God dwells, can never be conquered..$^{19}$ Our verb יצפנני in Psalm 27:5, then, may allude

nakh) maintains that the worshiper wants to be employed examining offerings. Craigie \& Tate as well as Goldingay follow Jon Levenson, "A Technical Meaning for $\mathrm{N}^{\mathrm{C}} \mathrm{M}$ in the Hebrew Bible," VT 35 (1985): 61-67, in surmising that the worshiper wishes to work as a diviner or temple prophet who seeks out oracles or performs some sort of augury in the temple. But it is neither possible nor necessary to pin down what job the worshiper wants in the temple. The verb לבקר suffices to make clear, as Terrien concludes (267), that "the psalmist favors ardently the holy ambition of 'serving' in the temple without interruption." Some commentators on this verse (Rashi, ibn Ezra, Hakham, and Mitchell Dahood, Psalms: Introduction, Translation, and Notes, 3 vols., AB [Garden City, NY: Doubleday, 1966-1970]) suggest another possible meaning of לבקר here, based on its similarity to the noun בקר (morning): to come to the temple each and every morning. This meaning would give warrant to NJPs's translation, "to frequent." But there are no clear attestations of such a verb, and the normal meanings of the verb in ancient Hebrew ("examine" and "be in charge") fit the cultic context of our verse perfectly well, making the recourse to an otherwise unattested meaning unnecessary.

18 The word was probably pronounced tsapān or tsafän in Ugaritic, with a long $a$ sound in the second syllable. It is not possible to know whether the middle consonant was pronounced $p$ or $f$.

Note also the correspondence of ומן צפן י-הו יסעדן in the fourth-century BCE Aramaic ver- 
to the idea of Zion as inviolable..$^{20}$ Because the worshiper hopes to remain in the Temple forever to serve the God dwelling there, the worshiper will be safely sheltered in the place of God's assured protection, Zion, which is God's mountain or צפון.

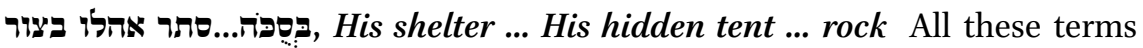
can refer to the Temple. In Psalm 76:3 סטפּה (shelter) refers explicitly refers to Jerusalem, which there is called both "Salem" and "Zion." (This word is related to the more familiar סֶכָָּ "hut, shelter." The more familiar word refers to God's hidden, heavenly abode amidst dark clouds in Ps 18:12 and Job 36:29.) (tent) also can refer to the Temple; see Psalms 15:1 and 61:5. Similarly, Dahood argues that צור, wich I translate as rock can mean "mountain."21 If this is so, that term might be an additional allusion to the Jerusalem Temple, which was located on the top of the hill known in biblical times as Zion and today as the Temple Mount. These overtones of the three words strengthen the verse's allusion to צפון as the mountain where God dwells.

בצור ירוממיני, High on a rock, He lifts me up Some commentators regard this last verset as odd; the previous ones talked about the speaker being hidden and thus protected; here the speaker is exposed for all to see (though presumably high on a rock where the enemies cannot get him). ${ }^{22}$ But sudden shifts in the imagery of a psalm are not uncommon; the psalmists feel free to use multiple comparisons in their figurative language, thus yielding an array of impressions to evoke the situation they have in mind.

sion of Psalm 20 in demotic script from Egypt (Papyrus Amherst 63, column xii, lines 1314) with ומציון יסעדך in the мт.

20 On the doctrine of Zion's inviolability, see, e.g., John Hayes, “The Tradition of Zion's Inviolability," JBL 82 (1963): 419-426; Ben Ollenberger, Zion, the City of the Great King: A Theological Symbol of the Jerusalem Cult, JSOTSupp (Sheffield: јsот Press, 1987).

21 Dahood, Psalms, commenting on 18:3.

22 Charles Augustus Briggs and Emilie Grace Briggs, A Critical and Exegetical Commentary on the Book of Psalms (New York: C. Scribner's Sons, 19o6-1907), ad loc., suggests reading רַַּּ, yielding the translation "in distress He lifts me up." But "lifting up" remains odd in that it exposes the worshiper where everything else here hides him. Ehrlich emends to ירום ממני, yielding the translation, "He protects me in His tent / on a crag too high for me." 


\section{Verse 6.}

יעתח, So now One might even translate this, "So" or "Therefore." In biblical Hebrew this word often draws a practical conclusion on the basis of what was stated immediately before. ${ }^{23}$

, I I should offer up ... should sing and play music The verbs are all lengthened prefix forms (cohortatives), which denote a wish or a hope rather than a fact.

יאזבחה...זיזבי תרועה I should offer up ... a celebration meal This could mean sacrifices that are offered accompanied by singing (so Rashi), or by joyful shouting, or by blasts of a trumpet or shofar (so ibn Ezra). Numbers 10:10 mentions sacrifices offered on holidays and New Moons along with trumpet blasts.

This verse contains two lines. The first, like all the lines before it in the poem, contains two versets. The second, which is the last line of the first stanza, contains three.

The last lines of the second stanza also has three versets (in verses 11-12). Both lines of the brief third stanza (verses 13-14) have three versets. Thus the threeverset line seems to mark the end of a stanza within this poem. For another case in which alteration between two- and three-verset lines demarcates stanzas, see Psalm 19. ${ }^{24}$

23 See F. Brown, S.R. Driver, and C. Briggs, A Hebrew and English Lexicon of the Old Testament (Oxford: Oxford University Press, 1907), 774a, § 2b (hereafter, вDB). Cf. Thomas Lambdin, Introduction to Biblical Hebrew (New York: Charles Scribner's Sons, 1971), 168-172, who notes this usage is especially common after הנה. But it can also occur after (which occurs in verse 5 , immediately before our verse) or even without any specific word meaning "since" or "because."

24 As Robert Gordis, "Psalm 9-10: A Textual and Exegetical Study," JQR 48 (1957): 119 n. 32, notes, three-verset lines often are used to end a text or a stanza: "The same stylistic procedure," Gordis points out, "is to be found in Ps. 13, 14, 16, 18, 19, 37, 47, 53, 55, 63, 73, 9o, 94, 103, 104, 111, 119, 125, 129, 140; Job, chaps. 10, 11, 19, 26." Cf. Wilfred G.E. Watson, Classical Hebrew Poetry: A Guide to Its Techniques, JSOTSupp (Sheffield: Sheffield Academic Press, 1984), 168-174, who makes the same claim about the stanza-formational role of what he calls the monocolon or orphan line-which is identical to what I am calling the third verset of a three-verset line. On this technique in Psalm 19, see Sommer, "Nature, Revelation, and Grace," 38 o. 


\section{Verse 7 .}

As we enter the second stanza, the tone abruptly changes from serene confidence to profound distress. The mode of referring to God changes as well: having spoken of God in the third person throughout the first stanza, the worshiper now addresses God in the second.

This verse contains a poetic line that can be divided into versets in more one way. If we read according to the Masoretic accents, ${ }^{25}$ it is a three-verset line:

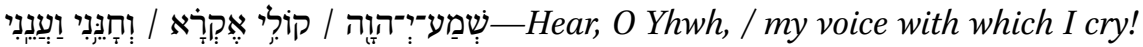
/ And show grace to me and answer me!26 But one can also read against the

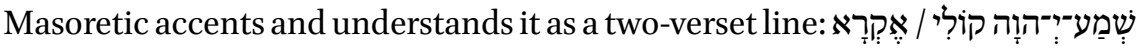

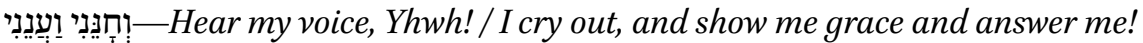
There is no need to call one of these ways of dividing the line right and the other wrong; some ancient Levites or scribes who performed this song probably sang it one way, while others sang it the other way. ${ }^{27}$ If we adopt the three-verset

25 Both Aleppo and Leningrad put מרכא (which is conjunctive) on רביע a אולי and a (which is disjunctive) on אקרא. In some Masoretic editions, such as the Rödelheim Psalter edited by Seligman Baer (which is followed by Vilna editions of the Miqra'ot Gedolot), we find a

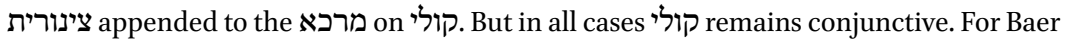

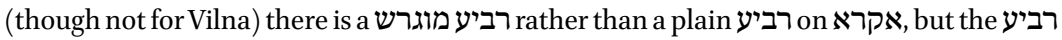

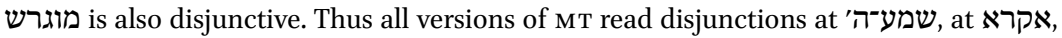
and at וענני

26 The absence of a specific word for "with which" in the second verset is perfectly normal in the terse language of biblical poetry, which often leaves out relative conjunctions. Against this translation, however, one might argue that the enjambment separating the verb in the first verset from its object in the second verset is unlikely in biblical poetry. (On the rarity of strong cases enjambment in biblical poetry, which overwhelmingly prefers endstopping, see Dobbs-Allsopp, On Biblical Poetry, 44-48, 135-139; Yaakov Kaduri, "Biblical Poetry: How Can It Be?" [in Hebrew], in The Literature of the Hebrew Bible: Introductions and Studies, ed. Zipora Talshir [Jerusalem: Yad Ben-Zvi Press, 2011], 297-298). But such an enjambment (in which a verb appears in one verset and its object in the next) is not altogether impossible, as the immediately preceding line of the poem shows. Alternatively, this three-verset line could be translated as three separate clauses: Listen, O Yhwh! / With my voice I call out! / And show grace to me and answer me.

27 Variation among performers is a normal phenomenon in performed texts, which is, of course, what the psalms were (and are). Woody Guthrie used to sing, "This land was made for you and $m e$ ": eight syllables, with stresses on the first, fourth, sixth, and eighth syllables - in other words, Guthrie sang the line as iambic tetrameter with an inverted initial foot. Bruce Springsteen performs this line differently: "This land was made for you a-and me": nine syllables, sung as free verse rather than following a conventional meter. Both performance traditions exist (and are available on YouTube), and there is no reason to think of Springsteen's revision of Guthrie's original as somehow invalid, or of Guthrie's as not yet meeting its true potential. 
lineation (as I have done in my translation above), the dividing line between the stanzas is even stronger: not only does the first stanza end with a triplet, but the second stanza begins that way as well. (This will also be the case at the divide between the second and third stanzas, as we will see in verses 11-13.)

\section{Verse 8 .}

A verse with multiple difficulties. Commentators have been troubled by (1) the opening word in the Hebrew, לד (which, following the lead of NJPS, I render as On Your behalf), (2) the plural form of the imperative verb בקשו (Seek), and (3) the idea of the worshiper's (mind) speaking. Various interpretations and emendations have been suggested. ${ }^{28}$ My rendering follows Rashi and ibn

28 Commentators suggest a variety of renderings and emendations for the first verset (MT's לך אמר לבי בקשו פני (לך). The simplest meaning of "To You." In that case, the worshiper's heart is telling God to seek the worshiper. This would make better sense if the imperative verb, בקשו ("Seek"), were in the singular, but the Hebrew has a plural verb, as it the worshiper were addressing more than one deity, which is impossible in light of the uncompromisingly monotheism of the Book of Psalms. If we emend the text by dropping the last letter of בקשו to make it singular, we can translate along with Martin Cohen, Our Haven, "I heard my heart say, 'Seek me' to You". Here, the worshiper is asking God to meet him halfway, as it were.

Dahood suggests a very small set of emendations that yield a very sensible text. He reads, לִּף אמר לבי בקש פניו (which merely alters the vocalization of the first word and transposes the odd 1 at the end of MT's בקש לקיו the end of the next word) and translates, "Come, said my heart, seek His face!" In this case, the worshipers mind or heart prompts him to seek God's presence. (Recall that in biblical Hebrew לב means both heart and mind.) Thus the worshipers avers that he is being reminded that God commanded us to seek Him (first verset of the line), and so the worshiper is seeking Him (second verset).

L. Delekat, Asylie und Schutzorakel am Zionheiligtum, HF1 (Leiden: Brill, 1967), 103, - suggests a somewhat similar and graphically plausible suggestion: "Your statement is: come, seek My face!"

Two manuscripts of the Lxx (Vaticanus and Alexandrinus) translate the first verset, "My heart said to You, 'I have sought Your face.' Your face, O Lord, I will seek." This is a sensible meaning, but it seems to reflect a radically different text that has than בקשו פני. No such Hebrew text is known, and it is difficult to understand the errors in scribal transmission that would have led from such a text to our MT. This version of LXX may attempt an exegetical revision of the underlying Hebrew. The Sinaiticus manuscript of Lxx translates, "My heart said to you, It/He sought my face." This seems to read

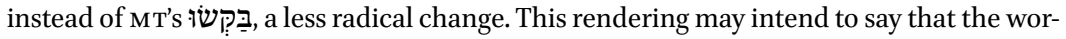
shiper's heart or mind said about God or on God's behalf that God was seeking out the worshiper, and then the worshiper replies in the next verset that he, correspondingly, will seek out God.

A final possibility has not been noted in the extensive literature on this verse: the last half of the verse (את־פניך י־הוה אבקש = It is You, Yhwh, that I seek) may be a gloss by 
Ezra to present a perfectly plausible rendering of MT's Hebrew without emendation. ${ }^{29}$ In the first poetic line found in this verse (On Your behalf my mind speaks: / "Seek Me out!"), the worshiper reports that his own mind or heart (לב has both meanings) spoke on God's behalf, urging him to seek out God's פנים (presence or face), which betokens especially God's favor, grace, and availability. In the subsequent poetic line (which is found at the end of verse 8 and the beginning of verse 9) the worshipers responds, declaring that he is seeking out God's presence, and begging God not to hide that presence.

This rendering raises a question, at least if it intends to keep the verb seek (בקשו) in the plural rather than emending to the singular form. Why does the worshiper's heart address the worshiper as a plural entity? Perhaps the plural imperative recognizes the divided nature of the worshiper's psyche: the speaker of this prayer is supremely confident in the first stanza and deeply nervous in the second stanza. We will return to the divided nature of the worshiper's mood below, in "Interpretation." Rashi suggests another answer to this question: The plural imperative might be directed towards to the people Israel generally. The worshiper's heart speaks on God's behalf, but in doing so, it speaks in the

a later scribe that comments on the previous words and is not intended as a part of the poem at all. Michael Fishbane, Biblical Interpretation in Ancient Israel (Oxford: Clarendon, 1985), 48-50, has pointed out that in biblical texts, the particle (which usually introduces a definite direct object or means "with") introduces an explanatory comment that identifies or specifies something ambiguous or problematic earlier in the same sentence. That may be the use of this particle in our verse. In fact poetry tends to use the particle את to introduce direct objects infrequently; in none of the cases where it might have been used in this psalm does it appear. Thus the word may have been ambiguous: In 8a, did the worshiper ask God to seek the worshiper out (which would have been the case if the imperative verb seek was originally in the singular, בקש)? Or did the worshiper's heart command the worshiper to seek God out? A glossator added the explanatory words in $8 \mathrm{~b}$, which attempt to make clear that it's the latter: the worshiper is talking about his own search for God's presence in 8a. If so, this reading is the earliest commentary on the Psalm. But the original intention of the psalmist (contra the reading of the glossator) may have been to ask God to seek the worshiper out. Such an interpretation fits the desperate tone of the second stanza quite well.

29 So too NJPS: "In Your behalf my heart says: / 'Seek My face!'” A similar solution is found in New Jerusalem Bible, which renders, "Of you my heart has said, 'Seek his face!" The Hebrew particular ל ל can mean "concerning, about"; this yields the NJB rendering. It can also "for, on behalf of," as Rashi, ibn Ezra, Radaq, and Meiri point out; this yields NJPs. For ל meaning "of, concerning, regarding," see в в в 515, column a, §g(b); and Ludwig Koehler et al., The Hebrew and Aramaic Lexicon of the Old Testament, trans. M.E.J. Richardson (Leiden: E.J. Brill, 2001), 508, col. b, §6 (= HALOT). For ל־ as "for, on behalf of," see BDв 514, col. a, §e; and HALOT 508 , col. b, §8. 
plural, as God issues this call not only to the individual worshiper but to all Israel. John Goldingay follows the same path and notes the significance of the plural verb: "The suppliant senses an internal voice speaking for Yhwh ... This internal voice is not just one that issues from the suppliant's individual spirituality, because the invitation it recalls is one addressed to the people of God," as in Psalm 105.4 and Zephaniah 2.3. ${ }^{30}$

את פשניך י־הוה אבקש, It is You I seek, O Yhwh The Hebrew word order emphasizes the direct object, פניך (literally, "Your face," "the front part of You") by putting it first.

\section{Verse 9.}

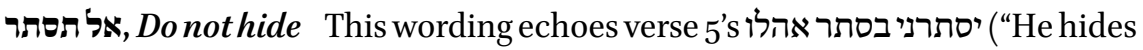
me in His hidden Tent"). In the first stanza, this verbal root (סתרינר) testified to God's assured protection and the worshiper's great confidence. Here, however, it lays bear the worshiper's fear that God might in fact abandon him. ${ }^{31}$ Thus the use of this one verbal root encompasses the core contrast of the whole psalm.

\section{Verse 10.}

This verse consists of a single poetic line. The two versets of the line display phonological parallelism, as they end with similar consonants: יאספני and עזבוני

כייאבי ואמי עזבוני, Indeed, my father and mother abandoned me This could be a reference to the most unlikely of events, that a parent will disavow a child; even in that extreme, God would still be reliable. Alternatively, the speak may refer to the likelihood of one's parents' death before one's own (so ibn Ezra). ${ }^{32}$

30 Goldingay, Psalms 1-41, ad loc.

31 On this contrast, see the astute comments of Meir Weiss, Ideas and Beliefs in the Book of Psalms (Jerusalem: Mosad Bialik, 2001), 67. Similarly, Herbert J. Levine, Sing unto God a New Song: A Contemporary Reading of the Psalms, Indiana Studies in Biblical Literature (Bloomington: Indiana University Press, 1995), 168, states, “The expression of both security and vulnerability through the root $s-t-r$ indicates the necessary interrelatedness of these emotions and the pivotal, unifying role played by $s-t-r$ in the psalm."

32 See further Shalom Paul, "Psalm xxvii 10 and the Babylonian Theodicy," VT 32 (1982): 489492; and Erhard Gerstenberger, Theologies of the Old Testament (Minneapolis: Fortress, 2002), 79 n. 130. 
, יי"הוה יאשפני But it is Yhwh who takes me in As is often the case, the prefix form evident in the verb allows several understandings. It can refer to the future: if someday my parents have abandoned me, God will take me in. Alternatively, the prefix form could refer to an ongoing action that began some time ago and continues in the present: ever since my parents abandoned me, God has been gathering me in. Further, it is possible that this verb is a short prefix form (recall that in most cases in biblical Hebrew, the regular prefix and the short prefix are identical; and that in poetry, the short prefix can mean not only the jussive but a preterite), in which case the verb could refer to an event in the past: when my parents abandoned me, God took me in. Finally, as a short prefix, the verb could have a volitive or modal meaning (what many biblical grammars label the jussive), expressing neither a fact about the present or past nor a prediction about the future, but the speaker's hope or desire for the future: if my parents abandon me, let God gather me in (in formal British English: God shall gather me in). ${ }^{33}$

\section{Verse 11.}

יהורנ, Parent me ... teaching me Literally, "teach me." The Hebrew term echoes a word that means "parents" (היריש). ${ }^{34}$ Thus this word picks up the previous verse's assertion that if mother and father abandon the worshiper, God will take over the parental role.

33 For this last possibility, see Goldingay, Psalms 1-41, ad loc., who notes, "In the context of the urgings of vv. 7-9 and 11-12, the yiqtol in v. 1ob is likely jussive." Against this, one might point out that יאספני is not the first word in its clause, and as Jan Joosten, The Verbal System of Biblical Hebrew: A New Synthesis Elaborated on the Basis of Classical Prose, Jerusalem Biblical Studies (Jerusalem: Simor Publishing, 2012), 315-317, points out, typically the jussive (that is, the short prefix forms used with volitive meaning) is in initial position in a clause. However, Joosten also notes a number of exceptions (ibid.), so that the possibility that we have jussive here cannot be ruled out. The contrast between the subjects of the two clauses (parents and God) might account for the placement of Yhwh at the beginning of the clause. Further, as Joosten points out (414), word order in poetry tends to be much freer than in prose, so that the placement of the verb is even less significant for distinguishing between the short and regular forms of the prefix.

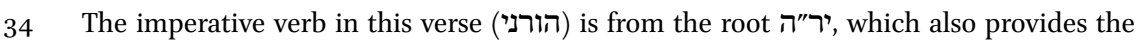

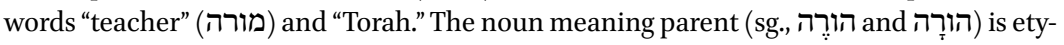
mologically unrelated to our verb, since it comes from a different root, הרדת, which means to give birth. But our imperative verb in 27:11 lends itself to a punning relationship to the words for parent because of their nearly identical pronunciation. 
דרכך,... Your path ... a level road A classic case of specifying parallelism: ${ }^{35}$ there are many types of ways or roads, but God's ways are level-Heb., פישי, a word that can mean a smooth road without bumps (rarer in the ancient world than in our own asphalt-filled one $)^{36}$ but can also denote righteousness and honesty.

למעין שזריר, While foes look on Or: "Because of those who watch me insiduously." My foes hope to see me stumble; indeed, they are trying to knock me down. So please put me on a smooth, straight road where I will walk with ease.

\section{Verse 12.}

, אל תתנגי בנפש צירי, Don't feed me to my enemies The word allows for several translations. It can mean "appetite, desire," and thus "will," (thus NJPs: "Do not subject me to the will of my foes"). It can also mean "throat," which allows us to translate the verse, "Do not put me into the throat of my foes."

,ייפח חמי, With unfair, violent testimony More literally, "a corrupt witness." The

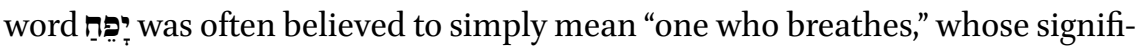
cance in this context is not altogether clear. On the basis of Ugaritic attestations of this word, however, we now know the word also means "witness," which fits our context perfectly. ${ }^{37}$

Our verse picks up on the ambiguity in verse 2's phrase, לאכל את בשרי. We saw above that that phrase can be an idiom meaning "to slander someone, to accuse someone unjustly," but it can also be understood as a portrayal of cannibalism ("to eat my flesh") that serves as a metaphor for damage the enemies hope to wreak on the worshiper. If we understand the opening words of our verse, with NJPS, as meaning "Do not subject me to the will of my foes," then our verse picks up on the idiomatic sense of phrase back in verse 2 . Our verse then extends this sense in the second and third versets of our line, with their references to false

35 On the prevalence of parallelism of specification in biblical poetry, see Robert Alter, The Art of Biblical Poetry (New York: Basic Books, 1985), 19-23, 57-59. Cf. James Kugel, The Idea of Biblical Poetry: Parallelism and Its History (New Haven: Yale University Press, 1981), 1523 .

36 Though the honoree of our Festschrift, like me, knows that many highways in our own State of New Jersey do an excellent job of teaching motorists what things were like in the ancient world.

37 See Samuel E. Loewenstamm, "Yāpēah, Yāpīaḥ, Yāpîạ̣" [in Hebrew], Leshonenu 26 (1962): 205-208, and Dennis Pardee, "YP ‘̣ 'Witness' in Hebrew and Ugaritic," VT 63 (2013): 99-108. 
witnesses. But if we understand the opening of our verse to mean, "Do not put me into the throat of my foes," then the image of cannibalism from the phrase in verse 2 returns here, rather than the idiomatic sense ("slander"). Both readings are valid. Some ancient worshipers, suffering due to false accusations or rumors, understood the phrasing the one way; others, who were in some crisis involving their enemies (and especially enemies who threaten physical violence), understood it the other way. Modern readers can legitimately take it either way as well.

\section{Verse 13 .}

The first word of this verse, לולא, means "if it were not the case that." The word in the Hebrew text appears with dots above and below it. (This is the case not only in vocalized editions of the MT but also in non-vocalized scrolls of the Psalter; the dots pre-date the work of the Masoretes. ${ }^{38}$ ) The dots probably indicate that already in late Second-Temple times or during the rabbinic era there were scribes who doubted that the word should be present. ${ }^{39}$ Indeed, ancient translation often omit the word לולוא; this is the case, for example, in the $\mathrm{LXX}^{40}$ The difference between versions with and without this word is substantial. LXX makes our verse a statement: "I believe I shall see the LORD's goodness in the land of the living." But when we include this word, our verse is the relative clause of a sentence that the speaker does not complete; our verse is the

38 See Israel Yeivin, Introduction to the Tiberian Masorah, trans. E.J. Revell, Masoretic Studies 5 (Missoula, Mo: Scholars Press, 1980), 44-46. According to Yeivin, a dot is to be placed above all four Hebrew letters of the word, but below only the first, third, and fourth letters. In fact various texts differ widely. Aleppo (followed by Breuer editions) have dots above and below all four letters; Leningrad (followed by BHS and Koren) has three dots above and below (and no dots for the letter 1); Baer's edition match Yeivin's description, with three dots above and four below.

39 So Yeivin, ibid.; as well as Emanuel Tov, Textual Criticism of the Hebrew Bible (Minneapolis, MN: Fortress Press, 1992), 55-57, both of whom discuss all fifteen occurrences of this phenomenon in scripture. Cf. the discussion of the ten cases in the Torah specifically in Saul Lieberman, Hellenism in Jewish Palestine (New York: Feldheim, 1950), 43-46, who notes that the Rabbis do not always understand them this way.

40 However, the previous verse in LXX ends with the word $\dot{\varepsilon} \alpha \nu \tau \hat{\eta}$, which could be understood to translate the word לה ("to herself, in herself"). No such word appears in the Hebrew

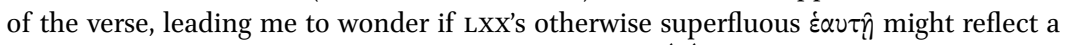
Hebrew text that had a (partially erased?) remnant of לולא. Qumran cannot come to our help here; our one scrap containing the end of Psalm $27\left(4 \mathrm{QPs}^{\mathrm{c}}\right)$ is not extant for this word, though it seems to me that the placement of the words later in the verse in the line, relative to the presumed beginning of the line, allows room for it. 
"if"-clause of a compound sentence whose "then"-clause never appears. ${ }^{41}$ To be sure, the intention of the implied then-clause is clear: what the speaker was thinking was something to the effect of, "If not for my faith that I will see God's goodness, I would be completely lost." The absence of the then-clause gives the impression that the speaker cannot bring himself to finish his sentence; his utterance brings him perilously close to an emotional place too dangerous to approach. The verse intends to make a statement of confidence, but the speaker cannot quite get the whole thing out. We have in a single verse, then, the whole back-and-forth of the psalm: the confidence of the first stanza and the anxiety of the second find are both manifest in this not-quite-complete expression of faith.

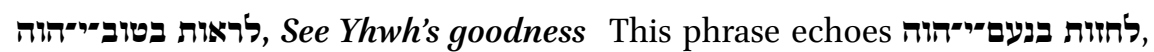
"to gaze upon the marvel that is Yhwh," in verse 4, helping to tie this stanza with the first stanza.

בארץ היים, while still alive Literally, "in the land of the living."42 Cf., e.g., Isaiah 38:11, 53:8; Jeremiah 11:19.

\section{Verse 14 .}

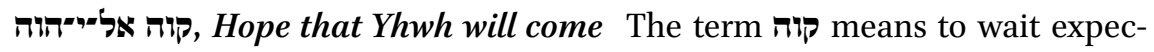
tantly for something, to hope for something. It denotes something beyond merely desiring but less than being fully confident that the thing or person will be attained.

Who speaks this line? Does someone else say this line to the worshiper, thus introducing a second voice into this poem? Or is this line, like every other line of the poem, said by the worshiper? If so, does he say these words to an audience at the Temple, or to himself?

41 Both Rashi and ibn Ezra see the then clause as appearing in the previous verse: "False witnesses would have risen against me if I had not been confident that I would see God's goodness." But this means that the then-clause would begin with כי, which seems unlikely, since can mean "if." Granted, we could sensibly translate כי לי here as "indeed." But beginning a then-clause with a word that typically introduces an if-clause would have invited confusion. Further, the clause at the end of the previous verse is the second verset of one poetic line, while our if-clause in verse 13 is the first verse of a new poetic line. A single compound sentence spread over the last part of one line and the first part of another would be highly irregular for biblical poetry, which by and large shuns strong enjambment of that sort. On biblical poetry's shunning of strong enjambment, see above, n. 26. 
The great biblical scholar Sigmund Mowinckel, followed by various commentators such as Craigie and Tate, argues that this line is said by a prophet, a priest, or a Levite at the Temple. ${ }^{43}$ Both Mowinckel and Joachim Begrich argued that Temple functionaries would regularly issue responses on God's behalf to the entreaties of worshipers, though in most cases these responses are not preserved in the psalms themselves. ${ }^{44}$ Our verse at the end of this psalm may be one of the rare instances where a prophetic or priestly oracle is in fact preserved in the biblical text. In this case, the psalm ends with a voice urging the worshiper to keep faith, rather than with a clear statement of belief by the worshiper himself. In other words, it ends with an implicit acknowledgement that the robust faith of the opening verses has been replaced with questioning hope, but not pure confidence.

Alternatively, it is possible that the worshiper recites this line. It is typical of both psalms of plea and of thanksgiving that the worshiper turns toward an audience in the temple to urge them to believe in God's saving power; indeed, the public acknowledgement of God's power is the very point of the thanksgiving song. Similarly, in many hymns of praise the speaker calls on others to praise God. But in those cases, the audience consists of more than one bystander, so the worshiper speaks to the audience with plural imperatives (see, e.g., Ps 30:5; 100:1-4). Here, however, the imperative verbs are all in the singular, which suggests that if the psalmist utters this verse, he is speaking to himself. (For a similar case, see the beginning and ending of Psalms 103 and 104, where the worshiper addresses the worshiper's own soul.) In that case, it is significant that the worshiper feels the need-and has the strength - to reassure himself. He is not completely confident, but urges himself to hope for God's salvation. (So Radaq. ${ }^{45}$ ) This line, presents "an apt summary of the

43 Sigmund Mowinckel, The Psalms in Israel's Worship, 2 vols., trans. D.R. Ap-Thomas (Oxford: Basil Blackwell, 1962), 2:59.

44 Joachim Begrich, "Das Priesterliche Heilsorakel," ZAW $5^{2}$ (1934): 81-92, argued that priests issued these oracles during Temple worship. Mowinckel, Psalms, 2:53-73, argued that prophets issued them, but also narrows the difference between his position and Begrich's be acknowledging $\left(2: 5^{6-58)}\right.$ that in light of the Books of Chronicles it becomes clear that in the Second Temple period Levites often worked as prophets in the Temple. A whole literature has developed around this issue; of particular import for confirming Begrich's original insight is Jonas Greenfield, "The Zakir Inscription and the Danklied," in Al Kanfei Yonah: Collected Studies of Jonas C. Greenfield on Semitic Philology, ed. Shalom Paul, Michael Stone, and Avital Pinnick (Jerusalem: Magnes Press, 2001), 1:75-92.

45 Radaq glosses this verse, "I say to myself all the time, 'Hope in the Lord. Do not pay attention to what the enemies say!' ... [and I say it] a second time so that I will constantly have hope, which will not leave my heart." Robert Harris writes (personal communication): 
psychology that informs this psalm,"46 because it is "another statement standing between plea and trust." ${ }^{47}$

\section{Interpretation}

\section{The Cry of an Asylum-Seeker?}

We noted above elements suggesting that the speaker in this psalm is the victim of unjust accusations (see comments to verses 2 and 12), and also that the speaker wishes to remain in God's Temple permanently (comments to 4 and 5, especially on לבקד = to serve in verse 4). The confluence of these elements led several scholars, including Hans Schmidt and L. Delekat, to suggest that this psalm originally functioned as a prayer of a person seeking asylum in the Temple. ${ }^{48}$ In ancient Israel, the altar at a temple was a place of safe refuge for a person accused unjustly of a crime. When a person in some ancient Near Eastern cultures was killed, relatives of the deceased had the right — and some people likely felt, the obligation - to kill his relative's killer. A law in Exodus 21:12-14, however, decrees that a person who committed accidental homicide could receive refuge in a local temple. (The legal collection in which this law is found, Exodus 20-23, is one of the oldest in the Bible, dating to the era when

"Thus, for this rabbi, hope is a practiced value ... One response to a sense of hopelessness is to repeat to oneself as a kind of slogan or mantra, 'I will remain hopeful, I will remain hopeful.' Despite all of the things I confront that make me experience a dreadful sense of hopelessness, I will set times to remind myself—verbally and internally— to take responsibility for changing my own state of mind."

46 Robert Alter, The Book of Psalms: A Translation with Commentary (New York:W.W. Norton, 2007), ad loc.

47 Goldingay, Psalms 1-41, ad loc.

48 See Hans Schmidt, Das Gebet der Angeklagten im Alten Testament, BZAW (Giessen: A. Töpelmann, 1928), and, more briefly, Hans Schmidt, "Das Gebet der Angeklagten im Alten Testament," OTE 18 (1927): 143-155; and Delekat, Asylie und Schutzorakel am Zionheiligtum, 154-258, and esp. the useful summary on 259-269. Other such psalms, according to Schmidt, include Ps 3, 4, 5, 7, 11, 13, 17, 26, 31, 54, 55, 56, 57, 59, 94, 140, and 142-a list far too long to be convincing. Pamela Barmash, Homicide in the Biblical World (Cambridge: Cambridge University Press, 2005), 81, argues that "[Delekat's] identification of the speaker of the Psalms as a fugitive killer is incorrect. While it is true that the Psalms present the enemies of the speaker as wanting to kill him and that the Psalms refer to Yhwh as protector and Yhwh's dwelling as a place a refuge, there is no indication that the refugee has been accused of homicide." Barmash is correct that Delekat overreads and spreads his net much too widely; the same may be said of Schmidt. But a few of the psalms they discussed may in fact been especially relevant to asylum seekers in ancient Israelite temples, and this seems especially true for Ps 27 . 
there were many local temples in ancient Israel, before the centralization of sacrificial worship in Jerusalem.) The avenging relative could kill the person who had caused the death of the relative if the relative found the killer before he arrived at a temple. But once the accidental killer was at the temple, he was safe. If, however, a court found him guilty of premeditated murder, he could be removed from the temple to meet his fate. ${ }^{49}$ Once safely ensconced in the temple, the accidental killer would be employed in some non-priestly or semipriestly capacity; if he was not from a priestly family, he could not officiate at sacrifices, but he could receive some other important role, and as a member of the temple staff, he had a ready source of food and shelter. ${ }^{50} \mathrm{He}$ would stay at the temple either for the rest of his life, or until he received amnesty, probably from a royal decree, or, following the logic of Numbers 35:9-34, following the death of a high priest, whereupon the deceased man's relatives lost their right to slay him. ${ }^{51}$ This notion of the temple as a place of asylum may have been applied even beyond the crime of accidental homicide, as the narrative about Solomon and Adonijah in 1 Kings 1:50-53 indicates. ${ }^{52}$

It is easy to see how Psalm 27 might have been especially meaningful for such an asylum-seeker. ${ }^{53}$ The people accusing him are "false witnesses and unjust accusers" (verse 12); they are committing slander against him (see comment to 2), perhaps by claiming that he committed intentional murder or some other intentional crime that would not allow him to remain in a temple, outside his pursuer's reach. Thus his claim that they want to "eat my flesh" (2) is doubly apt: as an idiom, this refers to their slander, but as a metaphor, it depicts the

49 Laws related to asylum appear in Num 35:9-29; Deut 19:1-13; and Josh 20:1-9. For an overview of this legal practice, see S. David Sperling, "Blood, Avenger Of," in Anchor Bible Dictionary, 6 vols. (New York: Doubleday, 1992), 1:763-764; as well as Barmash, Homicide in the Biblical World, 71-93.

50 On possible roles of the person who received asylum, see Delekat, Asylie und Schutzorakel am Zionheiligtum, 194-256. Regarding the seeker in our psalm as a singer or a guardian at a gate, see 194-207.

$5^{1}$ On the latter phenomenon, see Moshe Greenberg, "The Biblical Concept of Asylum," in Studies in the Bible and Jewish Thought (Philadelphia: Jewish Publication Society, 1995), 43-5o.

On other unintentional crimes that may have led people to seek asylum, see Delekat, Asylie und Schutzorakel am Zionheiligtum, 154-193.

53 On Ps 27 as a psalm of the asylum-seeker, see Schmidt, Gebet, 15-16, 27-29; Delekat, Asylie und Schutzorakel am Zionheiligtum, 103-104, 197-200; as well as the useful overviews in Jon Levenson, "The Jerusalem Temple in Devotional and Visionary Experience," in Jewish Spirituality from the Bible to the Middle Ages, ed. Arthur Green (New York: Crossroad, 1988), 39-43; Hans-Joachim Kraus, Psalms 1-59: A Continental Commentary, trans. Hilton Oswald (Minneapolis: Fortress, 1993), 333. 
violence they hope to do to him. As a result, he hopes to dwell in the temple "all the days of my life," which means that he will have a job there as a member of its staff (comment to verse 4). The various figures of the temple as safe haven, then, are intended quite literally, as are his pleas for help in the second stanza. ${ }^{54}$

The fact that this song was especially meaningful for asylum-seekers in ancient times, however, does not mean that only asylum-seekers recited it. The language of the psalms tends to be open-ended; many phrases psalms use can be read literally or metaphorically, and the psalms shy away from excessive specificity. Consequently, people in a variety of situations can adopt a given psalm as their own. This is the case with Psalm 27. Scholars including Schmidt and Delekat are right to connect this psalm with those who seek legal haven in a temple, but other worshipers, both in antiquity and today, also have found its wording apt for their experiences. For such worshipers, the references to the safe haven of the temple functions metaphorically, whereas for the asylumseekers, it functioned literally. For the asylum-seeker, the reference to serving in an official capacity in the temple at the end of v. 4 (ליבקר בהיכלי, "and to serve in His palace") was also literal; since the asylum-seeker would remain there for years or decades, he needed employment there. Other worshipers would probably not focus on the specific meaning of the verb לבקר (to serve, to have a position of responsibility"), reading it more vaguely as a reference to some sort of service in the temple rather than literally as a particular job.

\section{Faith and Doubt}

A striking element of Psalm 27 is its movement from confidence to need, from believing in God's reliability to worrying about God's absence. How can we account for the stark contrast between the first stanza (vv. 1-6), in which the worshiper joyously proclaims trust in God, and the second and third stanzas (vv. 7-12, 13-14), in which the worshiper betrays the fear that God might be far off?55

54 It is not possible to be sure whether this psalm functioned as a song of an asylum-seeker specifically in the Jerusalem temple or also in other temples prior to the centralization of sacrifical worship in Jerusalem in the late pre-exilic period. We saw that references to the temple's location on a hilltop and the allusion to צפון in verse 5 fit the Temple on Mount Zion well, the latter especially in light of Ps 48:3. On the other hand, other temples in ancient Israel were also located on hilltops (e.g., the temple at Samaria), and insofar as Yhwh was thought to dwell in other Israelite temples, we can readily imagine that they, too, might have been referred to as צפון.

55 On this extreme nature of this contrast at verse 7, see Jacob (Gerald) Blidstein, "T"hillim 27," Yavneh Review, Spring 1965, 21-23; Ellen Charry, Psalms 1-50 (Grand Rapids, MI: Baker 
Hermann Gunkel provides a simple answer to this question by asserting that this chapter contains two separate psalms, the first (vv. 1-6) a song of confidence and the second (vv. 7-14) a classic psalm of complaint and plea. ${ }^{56}$ It is not outside the range of possibility that a single chapter in the Book of Psalms might contain more than one composition. After all, there are cases in which a single psalm takes up more than one chapter: an alphabetic acrostic poem is spread over Psalms 9-10; Psalms 42-43 are also a single composition with a repeated refrain at 42:6, 42:12, and 43:5. Thus the converse-that two separate songs appear in one chapter-is certainly conceivable. But several scholars have successfully defended the unity of Psalm 27. Peter Craigie and Marvin Tate point out shared vocabulary that draws together what Gunkel regards as sep-

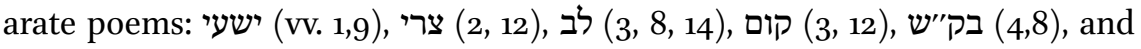
חיים $(4,13)$, in addition to the theme of seeing God's pleasantness or goodness $(4,13)$. Further, it is not quite the case that the first stanza is entirely confident while the second and third completely lack elements of faith. ${ }^{57}$ The first stanza contains intimations of the darker themes that appear later in the poem. Jacob Blidstein notes "the progressive deterioration of the roof overhead from 'stronghold (Ma-oz)' to 'hut (sukkah)' and finally 'tent' - a glimpse into the crisis that is as yet in the distance." ${ }^{n 8}$ As Goldingay astutely notes regarding v. 1, the worshiper's statement that he has no reason to fear draws attention to the fact that he apparently is worrying about something. ${ }^{59}$ Harris Birkeland also argues

Publishing Group, 2015), 139-141. Radaq attempts to minimize the contrast by reading verse 4 as a strictly spiritual request and regarding verse 7 as a reference back to the request in verse 4: the worshiper is confident in God's salvation from physical harm, but asks for the ability to commune with God in the temple or in heaven.

$5^{6}$ For this response, see Gunkel's commentary. Cf. Hermann Gunkel and Joachim Begrich, Introduction to Psalms: The Genres of the Religious Lyric of Israel, trans. James D. Nogalski, Mercer Library of Biblical Studies (Macon, GA: Mercer University Press, 1998), 190-191, where Gunkel emphasizes the connection of the song of confidence in 27:1-6 to the genre of the individual complaint. That is the genre we find in $7-12$, a circumstance that seems to move against Gunkel's view that the chapter contains two different songs. Nevertheless, his proposal has been widely accepted. In fact, I spoke imprecisely in note 53 when I said that Schmidt and Delekat discuss Ps 27 as an asylum psalm; in fact they regard it as containing two separate asylum psalms, one in verses 1-6, the other in 7-14.

57 Rolf Jacobson captures something crucial about the alleged gulf between the two parts of the psalm in Nancy deClaissé-Walford, Rolf Jacobson, and Beth LaNeel Tanner, The Book of Psalms, The New International Commentary on the Old Testament (Grand Rapids, MI: Eerdmans, 2014), 242: The psalm "speaks words of fear. And words of trust. The two are not as far removed from one another as one might imagine."

58 Blidstein, "T'hillim 27," 22.

59 Goldingay, Psalms 1-41, 392. He further points out (391) that the first stanza's "appearance of confidence is compromised by the fact that most of its lines have the short second cola 
for the unity of the psalm, pointing to the presence of elements of confidence in the second and third stanzas. ${ }^{60}$ In the first versets of the two poetic lines in v. 9, the worshiper begs God not to abandon the worshiper, but the second versets of both lines confirm that God is the worshiper's help and salvation. Similarly, in v. 13 the third stanza at least attempts to restate the confidence of the first stanza, albeit in a sentence that never reaches completion. ${ }^{61}$ These elements of unity demonstrate that Psalm 27 is a single composition that has to be interpreted as a whole. Of course, it is not outside the realm of possibility that each of the two sections once existed on its own, and that an editor, noticing

more characteristic of a lament." Indeed, the second verset of the first five lines of the poem are all quite negative.

6o Harris Birkeland, "Die Einheitlichkeit von Ps 27," ZAW 51 (1933): 218.

61 Gunkel further points out that v. 6 contains a vow, which is a standard way of ending a complaint song, while v. 7 begins like a classic psalm of complaint and plea. He argues that all this shows that one poem ends in 6 while another begins in 7; see pp. 114 and 116 of his commentary, and cf. Gunkel and Begrich, Introduction, 177, 184. But Birkeland, "Einheitlichkeit," 219, points out that to define v. 6 as an ending and v. 7 as a beginning on the basis of this formal criterion puts the cart before the horse. We can agree that v. 7 can only be a new beginning and cannot be a middle, or that 6 must be an ending, only if we put the psalm into a procrustean form-critical bed. Indeed, Birkeland points out (220), this is not the only psalm where a vow or a vocative and a plea appear in the middle: in Ps 9:15 we have a vow in the middle of a psalm, while in Ps 42-43 (a single song) the plea begins at 43:1, well into the poem. (Indeed, Gunkel himself noted that the vocative and plea that typically begin a complaint/plea do occur, albeit "far less frequently, in other positions"; see Gunkel and Begrich, Introduction, 152, and see esp. n. 13 there, in which Gunkel himself refers to Ps $42-43$. This observation vitiates his claim in his commentary, p. 116.) Sigmund Mowinckel, Psalmenstudien (Amsterdam: P. Schippers, 1966), 1:148, points out that we can simply regard Ps 27 as an individual complaint/plea that has an unusually long statement of trust in its first six verses. Such an overdevelopment of that statement of trust is atypical of biblical psalms but hardly impossible, as the similar case of Ps 42-43 shows. Such a development is quite typical of Akkadian psalms of plea: they often begin with invocations and statements of trust that are in effect fairly lengthy psalms of praise. Thus the first nine lines (out of a total of eighteen) of the plea to Shamash in Alan Lenzi, ed., Reading Akkadian Prayers and Hymns: An Introduction, sbl Ancient Near East Monographs (Atlanta: Society of Biblical Literature, 2011), 197-216, could have been a self-standing hymn to Shamash, but this does not mean that they are a different prayer from what follows; the hymn is a lengthy first element of the plea, at once acting as an extended vocative and an explanation for why the worshipper turns to Shamash. Similarly, the first nine lines (out of twenty-five) in the prayer to Marduk found in Lenzi, $313-325$, are a well-structured hymn to Marduk (as demonstrated by Tzvi Abusch, "The Form and Meaning of a Babylonian Prayer to Marduk," JAOS 103 [1983]), but that hymn is but a section of the longer plea psalm into which it is (Abusch shows) very well integrated at a literary-rhetorical level. The same may be said about Psalm 89, a complaint psalm that begins with a hymn of praise in verses $1-38$. 
the elements that link them, deliberately put them together to form the single composition that is now Psalm 27. Even in that case, however, it behooves us to ask what the editor was attempting to accomplish by putting them together, and especially by putting them together in the order they now have rather than the reverse.

We have seen that the first stanza hints at the source of fear even as it speaks of trust in God, while the second betrays worry over the possibility of God's distance while also asserting that God is a source of salvation. Then the third stanza's unfinished opening sentence acknowledges the possibility of life without trust in God while proclaiming that the psalmist indeed has this life-giving trust. The psalm closes with imperatives that call on the worshiper (and us) to wait hopefully for God. The fact that these imperatives are deemed necessary points to the existence of doubts that must be overcome. In this one psalm we have a beautiful and brief distillation of the entire Psalter as a book of doubt and faith. As the psalm moves back and forth between belief and distress, it "manifests powerful psychological verisimilitude," Robert Alter points out, because its emphasis on trust "does not preclude a feeling of fearful urgency in the speaker's plea to God."62

The movement from faith to doubt demands our attention, because the direction of the journey on which this psalm leads us is the opposite of what many readers might have expected of a religious text. Our worshiper does not grow into a more conventional piety over the course of the psalm, casting aside doubts to take up the armor of faith. Rather, the worshiper sets aside a seemingly ideal faith to take on a more realistic one. In fact Blidstein argues that the psalm criticizes the simplistic faith of the first stanza, whose God he labels "an ersatz divinity, a facile projection of [the worshiper] himself." ${ }^{63}$ Similarly, Ellen Charry, maintains that in the first stanza, the worshiper thinks that "he has God in his pocket."64 While the faith of that section seems on the surface to be stronger, the truth is that in that section, the worshiper speaks of God (always in the third person!) as something he knows about, but not someone whom he knows. In the second stanza, when the worshiper moves to the second person in order to address God directly, the worshiper at last achieves the experiential contact with God that he yearned for in verse 4 ("One thing I ask ..."). It is precisely when the worshiper speaks directly to God that doubt becomes prominent. God is no longer something the worshiper claims to know

62 Alter, Psalms, 91.

63 Blidstein, "T'hillim 27," 23.

64 Charry, Psalms 1-50, 139. 
all about; now God is a partner (though of course the senior partner) in a relationship, and relationships are slippery and unknowable in a way that does not conform to the simplistic faith of the first stanza.

The direction of the psalm's movement is crucial, because it models the maturing of an authentic relationship with God. A simple faith that asks no questions and admits no anxieties is not the most religious faith. A relationship that can articulate anxiety about the beloved's distance is ultimately stronger. As Charry writes, this psalm tells us that "unpleasant emotions are not to be repressed as untoward but to be healed through models that show how to handle them. Here, the psalmist gives permission to his audience to be emotionally conflicted in relation to God. He does not urge his hearers to 'grin and bear it' or 'put on a happy face,' and he does not disparage honest fear of Godabandonment ..." ${ }^{\prime 65} \mathrm{~A}$ faith that allows no doubt is hubris: when it claims to know for sure what God will and will not do, it denies God's freedom and invests far too much in the believer's impregnable security. Such a faith is the very opposite of true piety. The wavering faith of Psalm 27 is more honest, more humble, and therefore more deeply religious. This faith is neither Pollyannish nor naive; it is realistic about the fact that God seems absent at times.

It is also quintessentially Jewish in ending neither with fear nor with complete confidence but with hope (v. 14). The final verse of Psalm 27 recalls the Pentateuch, which does not conclude with entry into the Land of Israel and the fulfillment of God's promises. Deuteronomy 34 narrates not the victory of the hero, Moses, but his death. But that chapter also leaves us with the expectation that God's promises to Moses and to the patriarchs before him will nevertheless come to fruition in coming years with the victory of Moses' assistant, Joshua. Moses' life was a success not because he completed his task but because he did not desist from it - that is, because he lived up to the teaching of his latter-day disciple, Rabbi Ṭarfon in m. 'Abot 2:16 ("It is not incumbent upon you to complete the task, but you are not free to desist from it"). It is significant for the nature of the Jewish religion that the Torah ends on a note of hope rather than fulfillment. ${ }^{66}$ That tendency made it natural that the anthem

\footnotetext{
65 Charry, Psalms 1-50, 141.
}

66 Many modern scholars have suggested the possibility that in antiquity the Torah was a sixbook unit ending with Joshua. Thus it is vital to realize that all known forms of Judaism (and indeed, of Samaritanism) accept the five-book Torah ending with Deuteronomy. On the fateful nature of Judaism's decision to accord the highest canonical status to the Pentateuch and not to a Hexateuch, see James A. Sanders, Torah and Canon (Philadelphia: Fortress Press, 1972), 27-28, 52; and David Frankel, The Land of Canaan and the Destiny of Israel: Theologies of Territory in the Hebrew Bible (Winona Lake: Eisenbrauns, 2011), 25-29. (I am happy to thank Rabbi Joyce Newmark for calling this important passage in Sander's 
of the Zionist movement and later of the State of Israel is התקוה, "The Hope," rather than a song with a title like, say, הניצחון, "The Victory." ${ }^{67}$ Hope rather than perfect confidence characterizes the most mature Jewish faith: a readiness to admit one's fears, to look toward God expectantly while renouncing the claim to predict all God's actions. This faith is well displayed by the Psalm 27's journey from simple, trusting piety in its first stanza, through doubt in the second, to hope in the third.

\section{Bibliography}

Abusch, Tzvi. "The Form and Meaning of a Babylonian Prayer to Marduk." JAOS 103 (1983):3-15.

Alter, Robert. The Art of Biblical Poetry. New York: Basic Books, 1985.

Alter, Robert. The Book of Psalms: A Translation with Commentary. New York: W.W. Norton, 2007 .

Barmash, Pamela. Homicide in the Biblical World. Cambridge: Cambridge University Press, 2005.

Begrich, Joachim. “Das Priesterliche Heilsorakel." ZAW 52 (1934): 81-92.

Birkeland, Harris. "Die Einheitlichkeit von Ps 27." ZAW 51 (1933): 216-221.

Blidstein, Jacob (Gerald). "T'hillim 27." Yavneh Review, Spring 1965, 21-23.

Briggs, Charles Augustus, and Emilie Grace Briggs. A Critical and Exegetical Commentary on the Book of Psalms. ICc. New York: C. Scribner's Sons, 1906-1907.

Brown, F., S.R. Driver, and C. Briggs. A Hebrew and English Lexicon of the Old Testament. Oxford: Oxford University Press, 1907.

Charry, Ellen. Psalms 1-50. Grand Rapids, MI: Baker Publishing Group, 2015.

Cohen, Martin Samuel. Our Haven and Our Strength:The Book of Psalms. New York: Aviv Press, 2004.

Craigie, Peter, and Marvin Tate. Psalms 1-50. 2nd ed. wBC. Nashville: Thomas Nelson, 2004.

Dahood, Mitchell. Psalms: Introduction, Translation, and Notes. 3 vols. AB. Garden City, NY: Doubleday, 1966-1970.

work to my attention.) Because the Pentateuch is more sacred and authoritative in the Jewish canon than the rest of scripture, promise takes a central place in the shaping Jewish of identity, while fulfillment is secondary. The five-book Torah, the Scroll of Guidance, points towards a goal, but does not bring us all the way there. The Torah leaves us more in the position of Moses, looking towards a promised land, than Joshua, confidently entering it; and it is Moses, not Joshua, who is the prototypical Sage of the Jewish people.

67 Or a song such as שיר בית"ר (the hymn of the Revisionist Zionists), whose tone and lyrics are so contrary to התקוה" 
deClaissé-Walford, Nancy, Rolf Jacobson, and Beth LaNeel Tanner. The Book of Psalms. Nicoт. Grand Rapids, MI: Eerdmans, 2014.

Delekat, L. Asylie und Schutzorakel am Zionheiligtum. H F1. Leiden: Brill, 1967.

Dobbs-Allsopp, F.W. On Biblical Poetry. New York: Oxford University Press, 2015.

Ehrlich, Arnold. Psalme: Neu uebersetzt und erklaert. Berlin: M. Poppelauer, 1905.

Fishbane, Michael. Biblical Interpretation in Ancient Israel. Oxford: Clarendon, 1985.

Frankel, David. The Land of Canaan and the Destiny of Israel: Theologies of Territory in the Hebrew Bible. Winona Lake: Eisenbrauns, 2011.

Gerstenberger, Erhard. Theologies of the Old Testament. Minneapolis: Fortress, 2002.

Goldingay, John. Psalms 1-41. Baker Commentary on the Old Testament Wisdom and Psalms. Grand Rapids, MI: Baker Academic, 2006.

Gordis, Robert. "Psalm 9-10: A Textual and Exegetical Study." JQR 48 (1957):104-122.

Greenberg, Moshe. "The Biblical Concept of Asylum." In Studies in the Bible and Jewish Thought, by Moshe Greenberg, 43-5o. Philadelphia: Jewish Publication Society, 1995.

Greenfield, Jonas. “The Zakir Inscription and the Danklied." In Al Kanfei Yonah: Collected Studies of Jonas C. Greenfield on Semitic Philology. Edited by Shalom Paul, Michael Stone, and Avital Pinnick, 1:75-92. Jerusalem: Magnes Press, 2001.

Gunkel, Hermann, and Joachim Begrich. Introduction to Psalms: The Genres of the Religious Lyric of Israel. Translated by James D. Nogalski. Mercer Library of Biblical Studies. Macon, GA: Mercer University Press, 1998.

Hakham, Amos. The Book of Psalms [in Hebrew]. 2 vols. Da'at Mikra. Jerusalem: Mosad Harav Kook, 1979.

Hayes, John. “The Tradition of Zion's Inviolability." JBL 82 (1963): 419-426.

Holtz, Shalom. "God as Refuge and Temple as Refuge in the Psalms." In The Temple of Jerusalem: From Moses to the Messiah: Studies in Honor of Professor Louis H. Feldman. Edited by Steven Fine, 17-26. Leiden: Brill, 2011.

Hrůša, Ivan. Ancient Mesopotamian Religion: A Descriptive Introduction. Translated by Michael Tait. Münster: Ugarit, 2015.

Hrushovski, Benjamin. "Prosody, Hebrew." Encyclopaedia Judaica, 13:1195-1240. Jerusalem: Keter, 1971.

Hundley, Michael B. Gods in Dwellings: Temples and Divine Presence in the Ancient Near East. Atlanta: Society of Biblical Literature, 2013.

Joosten, Jan. The Verbal System of Biblical Hebrew: A New Synthesis Elaborated on the Basis of Classical Prose. Jerusalem Biblical Studies. Jerusalem: Simor, 2012.

Kaduri, Yaakov. "Biblical Poetry: How Can It Be?" [in Hebrew]. In The Literature of the Hebrew Bible: Introductions and Studies. Edited by Zipora Talshir, 287-306. Jerusalem: Yad Ben-Zvi, 2011.

Keel, Othmar. The Symbolism of the Biblical World: Ancient Near Eastern Iconography and the Book of Psalms. Translated by Timothy J. Hallett. New York: Seabury, 1978. 
Koehler, Ludwig, Walter Baumgartner, and Johann Jakob Stamm. The Hebrew and Aramaic Lexicon of the Old Testament. Translated by M.E.J. Richardson. Leiden: Brill, 2001.

Kraus, Hans-Joachim. Psalms 1-59: A Continental Commentary. Translated by Hilton Oswald. Minneapolis: Fortress, 1993.

Kugel, James. The Idea of Biblical Poetry: Parallelism and Its History. New Haven: Yale University Press, 1981.

Lambdin, Thomas. Introduction to Biblical Hebrew. New York: Charles Scribner's Sons, 1971.

Lenzi, Alan, ed. Reading Akkadian Prayers and Hymns: An Introduction. sBL Ancient Near East Monographs. Atlanta: Society of Biblical Literature, 2011.

Levenson, Jon. “The Jerusalem Temple in Devotional and Visionary Experience." In Jewish Spirituality from the Bible to the Middle Ages. Edited by Arthur Green, 32-61. New York: Crossroad, 1988.

Levenson, Jon. "A Technical Meaning for $\mathrm{N}^{\top} \mathrm{M}$ in the Hebrew Bible." VT 35 (1985): 6167.

Levine, Herbert J. Sing unto God a New Song: A Contemporary Reading of the Psalms. Indiana Studies in Biblical Literature. Bloomington: Indiana University Press, 1995.

Lieberman, Saul. Hellenism in Jewish Palestine. New York: Feldheim, 1950.

Loewenstamm, Samuel E. "Yāpēaḥ, Yāpīaḥ, Yāpîạ̣" [in Hebrew]. Leshonenu 26 (1962):205-208.

Mowinckel, Sigmund. Psalmenstudien. Amsterdam: P. Schippers, 1966.

Mowinckel, Sigmund. The Psalms in Israel's Worship. Translated by D.R. Ap-Thomas. 2 vols. Oxford: Basil Blackwell, 1962.

Ollenberger, Ben. Zion, the City of the Great King: A Theological Symbol of the Jerusalem Cult. JSOTSupp. Sheffield: Jsot Press, 1987.

Pardee, Dennis. "YPب̣ 'Witness' in Hebrew and Ugaritic." VT 63 (2013): 99-108.

Paul, Shalom. "Psalm xxvii 10 and the Babylonian Theodicy." VT 32 (1982):489-492.

Pritchard, James B., ed. The Ancient Near East in Pictures Relating to the Old Testament. 2nd ed. Princeton: Princeton University Press, 1969.

Sanders, James A. Torah and Canon. Philadelphia: Fortress Press, 1972.

Schmidt, Hans. "Das Gebet der Angeklagten im Alten Testament." oTE 18 (1927): 143155 .

Schmidt, Hans. Das Gebet der Angeklagten im Alten Testament. BZAw. Giessen: A. Töpelmann, 1928.

Sommer, Benjamin D. "Nature, Revelation, and Grace in Psalm 19: Towards a Theological Reading of Scripture." HTR 108 (2015): 376-401.

Sperling, S. David. "Blood, Avenger Of." Anchor Bible Dictionary, 1:763-764. New York: Doubleday, 1992.

Tov, Emanuel. Textual Criticism of the Hebrew Bible. Minneapolis: Fortress, 1992. 
Watson, Wilfred G.E. Classical Hebrew Poetry: A Guide to Its Techniques. JSOTSupp. Sheffield: Sheffield Academic, 1984.

Weiss, Meir. Ideas and Beliefs in the Book of Psalms [in Hebrew]. Jerusalem: Mosad Bialik, 2001.

Whitman, Walt. "The Bible as Poetry." Complete Prose Works, by Walt Whitman, 379382. Philadelphia: David McKay, 1892.

Yeivin, Israel. Introduction to the Tiberian Masorah. Translated by E.J. Revell. SBLMasS. Missoula, Mo: Scholars, 1980. 